\title{
What Determines Host Range and Reproductive Performance of an Invasive Ambrosia Beetle Euwallacea fornicatus; Lessons From Israel and California
}

\author{
Zvi Mendel ${ }^{1 *}$, Shannon C. Lynch ${ }^{2}$, Akif Eskalen ${ }^{2}$, Alex Protasov' ${ }^{1}$, Marcel Maymon $^{1}$ and \\ Stanley Freeman ${ }^{1}$ \\ ${ }^{1}$ Institute of Plant Protection, Agricultural Research Organization, The Volcani Center, Beit Dagan, Israel, ${ }^{2}$ Department \\ of Plant Pathology, University of California, Davis, Davis, CA, United States
}

OPEN ACCESS

Edited by:

Casper Nyamukondiwa,

Botswana International University of Science and Technology, Botswana

Reviewed by:

Diego Gallego,

University of Alicante, Spain

Andrea Battisti,

University of Padua, Italy

Davide Rassati,

University of Padua, Italy

*Correspondence:

Zvi Mendel

zmendel@volcani.agri.gov.il

Specialty section:

This article was submitted to

Pests, Pathogens and Invasions,

a section of the journal

Frontiers in Forests and Global

Change

Received: 17 January 2021

Accepted: 18 March 2021

Published: 21 April 2021

Citation:

Mendel Z, Lynch SC, Eskalen A,

Protasov A, Maymon M and Freeman S (2021) What Determines

Host Range and Reproductive Performance of an Invasive Ambrosia Beetle Euwallacea fornicatus,

Lessons From Israel and California.

Front. For. Glob. Change 4:654702.

doi: 10.3389/ffgc.2021.654702
This study examined the polyphagous shot hole borer (PSHB) Euwallacea fornicatus (Coleoptera; Scolytinae) native to Southeast Asia and concentrated on its wide host range in two of the invaded areas, California and Israel. Among the 583 examined tree species, 55.9\% were characterized as "non-reproductive hosts" and only $13.8 \%$ were characterized as "reproductive hosts," suitable for the $E$. fornicatus reproduction. Families that included $\geq 20$ species and genera with $\geq 10$ were considered for further analysis. The highest percentage of tree species suitable for reproduction was obtained for Salicaceae and Sapindaceae, whereas the lowest percentage of tree species belonging to this category were within the Rosaceae, Myrtaceae, and Magnoliaceae. The genera Acer, Quercus and Acacia displayed the highest percentage within the "reproductive host" category, with the former significantly higher from all seven of the studied genera. We found that all Brachychiton and Erythrina were attacked and none of the examined 20 Eucalyptus spp. were suitable for $E$. fornicatus reproduction. The results suggest discordance between host tree phylogeny and susceptibility to the E. fornicatus, indicating that trait correlation of susceptibility of different tree species to the E. fornicatus are the results of convergent evolution and not of a common descent. A theoretical model, suggesting the different possibilities of potential tree species becoming attractive or non-attractive to E. fornicatus attack, is described. It is suggested that the beetle reproduction success rate over a wide host range, as well as the long list of species belonging to the "non-reproductive host" category, is the outcome of interactions between the beetle fungal symbiont, F. euwallaceae, and sapwood of the attacked tree. The model suggests that a tree selected by the E. fornicatus may fall in one of three groups, (i) those in which $F$. euwallaceae is unable to develop, (ii) those tree species that slow the development of the fungus, and (iii) those that enable $F$. euwallaceae to thrive. Hence, the host range suitable for beetle reproduction is determined by development of $F$. euwallaceae. In general, PSHB does not distinguish between host species of the "non-reproductive host" and "reproductive host" categories.

Keywords: Euwallacea fornicatus, host range, ambrosia beetle, symbiotic fungus, Fusarium 


\section{INTRODUCTION}

Ambrosia beetles represent the earliest origin of fungus farming in insects (approximately $50 \mathrm{Myr}$ ), which emerged long after the origin of the subfamily Scolytinae (100-120 Myr) (Coleoptera: Curculionidae). Later origins include the species rich Xyleborini tribe (Curculionidae: Scolytinae), dating back to $21 \mathrm{Myr}$ (Jordal and Cognato, 2012). The habit of feeding on colonized fungi located in the nutritionally poor xylem by ambrosia beetles likely evolved several times with the feeding on fungal fruiting structures and spores, mostly with shifts to angiosperm hosts (Farrell et al., 2001). Ambrosia beetles generally occur as secondary insects in diseased trees or felled timber (FranckeGrosmann, 1967). The majority of ambrosia fungi and beetles are only able to colonize declining and freshly killed trees, and are not competitive in trees colonized by general wood-decaying fungi. Furthermore, collapse of the tree physiology boosts the development of wood decaying basidiomycetes, which compete with mutualistic fungi (Frankland, 1998), significantly limiting the time ambrosia beetles can remain in the wood. That in turn restricts evolution of family and social dynamics among the insects; nearly all ambrosia beetle species are only able to develop a single generation on a given tree, and all new individuals must thereafter disperse. Therefore, the most common relationship of ambrosia beetles with host trees is colonization of freshly killed tissues. However, there are also those that attack living trees, and those that survive in rotting tissues with a wood-decaying symbiont; most of these strategies are driven by fungal symbionts' metabolism (Hulcr and Stelinski, 2017).

Although healthy trees are normally unsuitable to attack by bark and ambrosia beetles, some species are reported to attack and eventually kill live, apparently healthy non-coniferous trees, but this represents a minority of species to date (Grousset et al., 2020). Among the ambrosia-feeding scolytids, Xyleborini are the most numerous and widely distributed tribe. Their cryptic nature; polygamous, sib-mating system; and wide host range foster their distribution through commerce and establishment in new areas (Rabaglia et al., 2006). In scolytine-fungus ectosymbioses, the fungi are inoculated by the beetles into plant tissues where they grow for a period of time independent of the host, before being reacquired by offspring as callow adults (Six, 2012). The mycangia, structures in the beetles' mandible, mesonotum, or elytron that harbor the symbiotic fungi, play a critical role in this process (Skelton et al., 2019).

For ambrosia beetles, the adoption of a strictly mycophagous habit may have led to extensive species radiations in the Xyleborini (Jordal et al., 2000). However, these radiations occurred mainly in tropical rainforests, where both warm temperatures and high humidity favor fungal development (Atkinson and Equihua-Martinez, 1986). The high species richness of the tropical rainforests may have shaped the strategy of fungi-beetles symbiont partnerships allowing colonization of large number of host tree species, which also makes them successful invaders. Ambrosia beetles that attack live trees are mostly those surviving under stressed conditions. Stress may arise from various abiotic factors; including flooding, drought, mechanical damage (such as windbreak and snowbreak), freezing, ozone exposure, graft incompatibility, non-suitability for development in particular site conditions, excessive or improperly timed nutrient supplies, and biotic factors caused by pathogens and other insect pests (Ranger et al., 2010; Ploetz et al., 2013; Hulcr and Stelinski, 2017). Ploetz et al. (2013) referred to the alarming increase in ambrosia beetle-associated diseases and of trees in various environments, and coined their surprising impacts and dramatic increases as "black swan events" in tree health.

Many of the studied invasive species of the Xyleborini tribe seem to attack living and/or apparently healthy trees growing within non-native ornamental, horticultural, and forested habitats (Weber and McPherson, 1984; Atkinson et al., 1988; Oliver and Mannion, 2001; Henin and Versteirt, 2004; Keshavareddy et al., 2008). For example, in the United States, camphor trees seemed to be more resistant to vascular wilt disease caused by Raffaelea lauricola, native to areas of the fungal host Xyleborus glabratus, than American species of Lauraceae (Fraedrich et al., 2014). Native Xyleborini in turn attack live exotic tree species as demonstrated in the case of Euwallacea perbrevis in Sri Lanka (mentioned as Xyleborus fornicatus, Danthanarayana, 1968; Walgama, 2012) or Euwallacea fornicatus (Coleoptera: Curculionidae: Scolytinae) in India (Mote and Tambe, 1991), China (Li et al., 2016), and in Vietnam (Anon., 2014). This phenomenon was also evident in other groups of ambrosia beetles; for example, Megaplatypus mutatus (Platypodinae) native to Argentina that causes serious wilting of exotic Casuarina cunninghamiana in Argentina and Populus spp. in Italy (Alfaro et al., 2007). Hulcr and Dunn (2011) suggested that virulence of ambrosia beetles in invaded ranges is often triggered when three factors coincide: (i) invasion into territories with naïve trees, (ii) ability of the associated fungus to either overcome resistance of the naïve host or trigger a suicidal overreaction, and (iii) an "olfactory mismatch" in the insect whereby a subset of live trees is perceived as "weakened," thus suitable for colonization.

Ambrosia beetles belonging to the Xyleborini are typically recognized as stenophagous (feeding on few species of fungi) whereas the polyphagous nature of their fungal symbionts is an acquired property in diverse habitats such as the tropical rainforests (Beaver, 1977, 1979; Kirkendall, 1983; Atkinson et al., 1990). Thus, many of the studied Xyleborini are found on a large number of tree species (Wood and Bright, 1992). Browne (1961) who studied the Euwallacea spp. (as Xyleborus spp. in the group Euwallacea) in Malaysia (Malaya) indicated that in natural conditions the species are not, as a general rule, highly selective in their choice of hosts. For example, Browne (1961) listed 19 hosts in 14 families in Malaysia for Euwallacea similis. However, some of them such as E. fornicatus (s.l.) showed signs of distinct preferences to certain host trees. Hulcr et al. (2007) examined host specificity of ambrosia beetles from a lowland rainforest in Papua New Guinea and found that they are broad generalists as $95 \%$ of the species did not show any preference for a particular host species or clade. Xylosandrus compactus is known to infest more than 225 species of plants, belonging to 62 families (Ngoan et al., 1976; CABI, 2020). Xylosandrus crassiusculus also occurs in a very wide variety of host plants; 
Schedl (1963) listed 94 tree species in 28 families in Africa, and 63 tree species in 34 families outside Africa. Xyleborus affinis has a pan-tropical distribution infesting some 300 woody hosts (Schedl, 1963; Wood, 1982; Rabaglia et al., 2006), 150 species in Africa alone (Francke-Grosmann, 1967). Xylosandrus germanus exhibits the capability of attacking a diverse range of more than 200 tree species (Weber and McPherson, 1983).

Euwallacea is a monophyletic genus that is morphologically diverse (Storer et al., 2015). The first description of Xyleborus fornicatus Eichh. (Euwallacea fornicatus), a twig boring ambrosia beetle, was made by Eichhoff in 1868 from a specimen collected in Sri Lanka (then Ceylon) from an unknown plant (Speyer, 1917). During the past two decades, exotic Asian Euwallacea spp. have been detected in several areas in the West where they attack and reproduce in living woody hosts. At first, the main concern was the avocado industry, however, later it was found that these species inflict serious damage on native and exotic trees in urban landscapes and even in native forests (O’Donnell et al., 2015; Boland, 2016; Mendel et al., 2017; Paap et al., 2018). A recent taxonomic review of the species complex by Smith et al. (2019) proposed the following classification: Euwallacea fornicatus [=E. tapatapaoensis (Schedl, 1951); =E. whitfordiodendrus (Schedl, 1942) syn. res.]. Members of the Euwallacea fornicatus species complex and their variety of ambrosia symbiotic fungi further confirms that the relationship between the beetles and fungi are more likely promiscuous in native areas, as opposed to strictly obligate with a specific combination of fungi of any of the beetle species, as observed in invaded areas (Carrillo et al., 2019).

Stouthamer et al. (2017) reported that the native range of the polyphagous shot-hole borer (PSHB), Euwallacea fornicatus might encompass Northern Thailand, Vietnam, China, Taiwan, and Okinawa. Three symbiotic fungi: Fusarium euwallaceae, Graphium euwallaceae, and Paracremonium pembeum were detected in the larvae and adult PSHBs and from the brood galleries of the beetles in four tree species (Freeman et al., 2012, 2019; Lynch et al., 2016). The mutualism between xyleborine beetles within the genus Euwallacea and members of the Ambrosia Fusarium Clade (AFC) represents one of 16 known evolutionary origins of fungiculture by ambrosia beetles (O’Donnell et al., 2015; Aoki et al., 2019). AFC symbionts are unusual in that some are plant pathogens that cause significant damage in naïve natural and cultivated ecosystems (Kasson et al., 2013).

Fusarium euwallaceae is a well-characterized fungal symbiont of E. fornicatus inciting Fusarium dieback on many host plants in Israel, California, and South Africa. The discovery of additional fungal symbionts within ambrosia beetle mycangia was expected as already Baker and Norris (1968) showed that as a complex, the three fungi provided the nutrients essential for reproduction of Xyleborus ferrugineus; thus, suggesting that G. euwallaceae and $P$. pembeum together with $F$. euwallaceae occur as a community for beetle proliferation and survival (Lynch et al., 2016; Freeman et al., 2019).

Many bark and ambrosia beetle species are attracted by ethanol (e.g., Rabaglia et al., 2006; Reding and Ranger, 2020). Ethanol is present in some tissues of healthy trees, but in weakened trees, it increases dramatically due to limited oxygen availability resulting from a variety of physiological stresses (Kimmerer and Kozlowski, 1982; MacDonald and Kimmerer, 1991). Some Xyleborini species are considered non-ethanolresponsive ambrosia beetles that may exploit host volatiles induced by the symbiotic fungi (Hulcr et al., 2011) or those volatiles related directly to the host chemistry (Martini et al., 2017). Observations in Israel suggested that PSHB does not respond to ethanol (Mendel and Freeman, unpublished data). Attraction to host volatiles may be misleading as the beetles often attack host trees unsuitable for reproduction (Kendra et al., 2011; Mendel et al., 2017). The PSHB is capable of colonizing living tissues of angiosperm hosts, which may help explain the beetle's unique semiochemical ecology (Kendra et al., 2017). However, data of Li et al. (2016) did not suggest that the beetle is an aggressive colonizer of living and healthy trees, since nearly all individuals were collected in that study from weak, diseased, or dead host plants. Cooperband et al. (2017) identified two pheromone compounds, 2-heneicosanone and 2tricosanone, for the three members belonging to the E. fornicatus species complex present in North America. Gomez et al. (2019a) suggested that these are probably involved in social behavior with colonized galleries.

The effect of imitating the PSHB attack by multiple inoculations of its symbiont Fusarium euwallaceae clearly indicated that the fungus colonizes host plant tissues in a localized manner and is not systemically transmitted throughout the xylem tissues (Freeman et al., 2019). Multiple attacks by beetles are needed to weaken main limbs and branches of avocado "Hass" (Mendel et al., 2017) as well as other tree species (authors' observations in both California and Israel). To the contrary, Xyleborus glabratus in North America represents an extreme case: the spores of its symbiont, Raffaelea lauricola migrate passively through the xylem, causing the tree to respond with gums and tyloses, which impede water transport and cause foliage wilting and branch dieback; complete seedling wilt and plant mortality can occur within a few weeks (Inch and Ploetz, 2012; Inch et al., 2012).

This study concentrates on the wide host range of PSHB in two of the invaded areas including 207 and 52 tree species in California (Eskalen et al., 2013) and Israel (Mendel et al., 2017), respectively, and more new records, accumulated since these studies were published. The objectives of the present work were: (i) to analyze results of the surveys that were conducted in Israel and California urban areas and parks totaling 583 tree species, (ii) to clarify the distinct susceptibility between host species, and (iii) to suggest a model which may explain the lack and differences in reproduction success of the PSHB in different host tree species.

\section{MATERIALS AND METHODS}

\section{Host Plant Survey}

The surveys were conducted in Israel between 2013 and 2020 in different growth habitats, including public parks, botanical gardens, home backyards, ornamental landscapes of different Kibbutzim and commercial avocado orchards with the 
surrounding woody vegetation. Interactions with stakeholders, landscape managers and gardeners initiated many visits to the beetle infested trees. The surveys were also based on information conveyed by foresters and landscape inspectors regarding susceptible indigenous tree species in their natural habitats; maples and oaks in particular (see also Mendel et al., 2017). In California, most of the trees were visited and identified to species at the LA Arboretum and the Huntington Library, Art Collections and Botanical Gardens in Los Angeles County, and native and urban forests. Each botanical garden covers approximately 48 ha and in general, the species collections housed in each location are different and genetically diverse (see also Eskalen et al., 2013).

\section{Host Tree Type Definition}

We defined three categories of host trees with respect to the PSHB. The "reproductive host" was termed when eggs, larvae, pupae or callow adults of the PSHB were detected in the exposed galleries of attacked tree species and Fusarium euwallaceae was isolated. The "non-reproductive host" referred to typical attack symptoms on tree species, viz., lesions and/or penetration holes that were observed and (in most cases) F. euwallaceae was isolated without any signs of beetle reproduction. The "nonattacked host" referred to individuals of tree species that were not affected although they were observed in the vicinity (a radius of $25 \mathrm{~m}$ ) of attacked trees, observed under similar conditions, on at least two separate sites. Owens et al. (2019) found that $80 \%$ of marked Euwallacea nr. fornicatus were recaptured within 30$35 \mathrm{~m}$ of the release point. "Attacked tree species" was termed for "suitable for reproduction" and "non-reproductive," combined.

\section{Examination of the Sampled Trees}

In Israel, the bark of suspect infested trees was removed to expose the beetle's gallery. Beetles were collected and identified, and in most examined trees a core sample $(0.5 \times 10 \mathrm{~cm})$ was removed with a tree increment borer (Haglöf group, Långsele, Sweden) or knife for isolation of the common symbiotic fungus, Fusarium euwallaceae, as described by Freeman et al. (2012). Tree species that were termed as highly susceptible, produced extensive beetle populations and significant numbers of these hosts were eventually killed (Mendel and Freeman, unpublished data). All trees characterized as "non-reproductive" were grown on sites with ascertained "reproductive hosts." In California, tissue samples from each tree species showing symptoms characteristic of dieback (one tree per species) were collected by extracting symptomatic tissue from the trunk with a sterilized knife to a depth beyond the cambium. Samples were returned to the laboratory (University of California, Riverside) for morphological and molecular identification of the beetle, the fungus, or both. If visible, beetles were collected and placed immediately into $95 \%$ ethanol for further molecular identification (Eskalen et al., 2013).

\section{Data Analysis}

The 583 tree species included in the analyses with their specific affiliation included; their family, genera, category with respect to the beetle attack and area of examination, as listed in
Supplementary Table 1 . The tree species were sorted according to category, and the occurrence of trees of all three categories within each family and genus, according to number of examined species in each taxa. Indigenous sampled tree species for California and Israel were also analyzed separately. The tree category patterns, analyzed for the eight families, included 20 or more species and eight genera, which included 10 or more species. Overall association between species and category and between genera and category was established by the Likelihood Ratio (LR) Chi-square Test. Following significant association in both cases $\left(\chi^{2}{ }_{(14)}=117.6, p<0.0001, \chi^{2}{ }_{(14)}=65.7, p<0.0001\right.$, respectively), pairs of species and pairs of genera were compared for incidence of each of the three categories separately by $\chi^{2} L R$ Test with one degree of freedom.

\section{RESULTS}

\section{General Information About the Sampled Trees}

The 583 examined tree species fell into the three host categories, the majority of which $55.9 \%$ were designated as "nonreproductive hosts" while only $13.8 \%$ as "reproductive hosts," suitable for the PSHB reproduction (Table 1). Occurrences of trees belonging to all three categories in a certain family or a genus is related to the sampling size. Thus, only $3.1 \%$ of the examined genera and $23.2 \%$ of the examined families nested species of all three categories. However, when genera with $\geq 5$ species and families with $\geq 10$ species were assessed, these values rose to 30 and $88.9 \%$ for genera and families, respectively (Table 1). The number of examined tree species varied markedly between the representative genera and families, therefore, only genera that included $\geq 10$ species or families with $\geq 20$ (Table 2) were considered for further analysis. Supplementary Table $\mathbf{1}$ (as Supplementary Data) lists all examined tree species with respect to their taxonomic affiliation (genus and family), susceptibility to the PSHB and geographic location; 451 species were examined in California, 97 in Israel and an additional 35 in both locations.

TABLE 1 | Summary of host tree information.

\begin{tabular}{llcc}
\hline $\begin{array}{l}\text { Taxonomic } \\
\text { level of hosts }\end{array}$ & Groups & $\begin{array}{c}\text { Number } \\
\text { examined }\end{array}$ & $\begin{array}{c}\text { \% included all three } \\
\text { host categories }\end{array}$ \\
\hline Species & Total & 583 & - \\
& "Suitable for reproduction" & 81 & - \\
& category & & - \\
& "non-reproductive" category & 326 & - \\
& "Not attacked" category & 176 & 0.8 \\
Genera & Total & 259 & 33.3 \\
& Including 1-4 sampled tree & 238 & \\
& species & & 23.2 \\
& Including $\geq 5$ sampled tree & 21 & 6.2 \\
& species & & 88.9
\end{tabular}


The examined indigenous tree species sampled in each area are listed in Table 3; they represent a small fraction of the total species examined. The percentage of tree species associated with the "reproductive" category is similar to both California and Israel, and all belong to the same four genera: Acer, Platanus, Populus, and Quercus (Table 3).

\section{Family Level Examination}

Among the eight analyzed botanical families of the examined trees, only Fagaceae and Myrtaceae were significantly different within the three host categories. Some families did not differ from each other in any of the categories for the two following groups: (1) between Fabaceae, Magnoliaceae, and Malvaceae, and (2) between Fagaceae, Sapindaceae, Salicaceae, and Rosaceae (Table 4). Fagaceae significantly differed from Myrtaceae in all three tree categories; any other pair comparisons displayed a significant difference only for one or two of the categories (Table 4). Comparison of occurrences of tree species suitable for reproduction and all attacked tree species (attacked tree species $=$ suitable for reproduction + "non-reproductive") of

TABLE 2 | Families studied with respect to number of genera and related host species information according to the three categories of susceptibility to the PSHB.

\begin{tabular}{|c|c|c|c|c|c|c|c|c|c|}
\hline \multirow[t]{2}{*}{ Family } & \multirow[t]{2}{*}{ Genera } & \multicolumn{3}{|c|}{ Host species category } & \multirow[t]{2}{*}{ Family } & \multirow[t]{2}{*}{ Genera } & \multicolumn{3}{|c|}{ Host species category } \\
\hline & & Reproductive & Non-reproductive & Not attacked & & & Reproductive & Non-reproductive & Not attacked \\
\hline Altingiaceae & 1 & 1 & 1 & - & Lythraceae & 2 & - & & 3 \\
\hline Anacardiaceae & 8 & 1 & 4 & 6 & Magnoliaceae & 2 & 2 & 27 & 2 \\
\hline Apocynaceae & 5 & - & 1 & 4 & Malpighiaceae & 2 & - & 2 & \\
\hline Arecaceae & 13 & 2 & 6 & 7 & Melianthaceae & 1 & - & 1 & \\
\hline Asparagaceae & 2 & - & 1 & 1 & Menispermaceae & 1 & 1 & 1 & \\
\hline Asphodelaceae & 2 & - & & 2 & Monimiaceae & 1 & - & 1 & \\
\hline Asteraceae & 3 & - & 2 & 1 & Moraceae & 3 & 3 & 7 & 1 \\
\hline Betulaceae & 5 & 1 & 5 & 4 & Moringaceae & 1 & - & 1 & \\
\hline Buddlejaceae & 1 & - & 1 & - & Onagraceae & 1 & - & 2 & \\
\hline Burseraceae & 2 & - & 1 & 1 & Papaveraceae & 1 & - & 1 & \\
\hline Cactaceae & 1 & - & - & 1 & Papaveraceae & 1 & - & & 1 \\
\hline Cannabaceae & 1 & 1 & 2 & 2 & Papilionaceae & 1 & - & & 1 \\
\hline Caprifoliaceae & 1 & - & - & 1 & Pinaceae & 3 & - & 4 & 6 \\
\hline Casuarinaceae & 1 & - & 1 & - & Pittosporaceae & 2 & - & 2 & 2 \\
\hline Celastraceae & 2 & - & - & 2 & Platanaceae & 1 & 7 & 2 & \\
\hline Cercidiphyllaceae & 1 & - & - & 1 & Poaceae & 2 & - & 1 & 1 \\
\hline Clethraceae & 1 & - & - & 1 & Podocarpaceae & 2 & - & 1 & 4 \\
\hline Combretaceae & 1 & - & 1 & - & Polygalaceae & 1 & - & & 1 \\
\hline Cornaceae & 4 & - & 6 & - & Proteaceae & 4 & - & 2 & 2 \\
\hline Fabaceae & 31 & 16 & 71 & 6 & Scrophulariaceae & 1 & - & & 2 \\
\hline Fagaceae & 3 & 12 & 20 & 9 & Simaroubaceae & 1 & 1 & & \\
\hline Fouquieriaceae & 1 & - & - & 1 & Solanaceae & 3 & - & 1 & 2 \\
\hline Garryaceae & 1 & - & - & 1 & Tamaricaceae & 1 & - & & 1 \\
\hline Ginkgoaceae & 1 & - & - & 1 & Taxodiaceae & 1 & - & 1 & \\
\hline Hernandiaceae & 1 & - & - & 1 & Theaceae & 3 & 1 & 13 & 3 \\
\hline Iteaceae & 1 & - & - & 1 & Ulmaceae & 3 & - & 7 & 1 \\
\hline Juglandaceae & 3 & 2 & 4 & 1 & Urticaceae & 1 & - & 1 & \\
\hline Lamiaceae & 1 & - & - & 1 & Verbenaceae & 3 & - & 3 & 1 \\
\hline
\end{tabular}


TABLE 3 | Examined indigenous tree species in California and Israel, and category as related to their susceptibility to the PSHB.

\begin{tabular}{|c|c|c|}
\hline Category & California (25 species) & Israel (18 species) \\
\hline \multirow[t]{8}{*}{ "Reproductive" } & Acer macrophyllum & Acer obtusifolium \\
\hline & A. negundo & Platanus orientalis \\
\hline & Platanus racemosa & Populus euphratica \\
\hline & Populus fremontii & Quercus calliprinos \\
\hline & P. trichocarpa & Q. infectoria \\
\hline & Quercus agrifolia & Q. ithaburensis \\
\hline & Q. engelmannii & \\
\hline & Q. lobata & \\
\hline$\%$ & 32.0 & 33.0 \\
\hline \multirow[t]{8}{*}{ "Non-reproductive" } & Juglans californica & Cercis siliquastrum \\
\hline & Pithecellobium glandulosa & Olea europaea \\
\hline & Prunus ilicifolia & Pistacia atlantica \\
\hline & P. mexicana & P. palestina \\
\hline & Umbellularia californica & Populus alba \\
\hline & & Quercus look \\
\hline & & Rhamnus alaternus \\
\hline & & Ziziphus spina-christi \\
\hline$\%$ & 20.0 & 44.4 \\
\hline \multirow[t]{12}{*}{ "Non-attacked" } & Bocconia arborea & Cupressus sempervirens \\
\hline & Bursera odorata & Pinus halepensis \\
\hline & Calocedrus decurrens & Pistacia lentiscus \\
\hline & Euonymus bungeanus & Pyrus amygdaliformis \\
\hline & Maytenus boaria & \\
\hline & Myoporum laetum & \\
\hline & Pinus torreyana & \\
\hline & Quercus emoryi & \\
\hline & Sambucus mexicana & \\
\hline & S. nigra & \\
\hline & Sequoia sempervirens & \\
\hline & Umbellularia californica & \\
\hline$\%$ & 48.0 & 22.6 \\
\hline
\end{tabular}

${ }^{1} A$ "reproductive tree" was termed when eggs, larvae, pupae or callow adults of the PSHB were detected in the exposed galleries of attacked trees and Fusarium euwallaceae was isolated. An "Non-reproductive tree" referred to typical attack symptoms, viz., lesions and/or penetration holes that were observed and (in most cases) F. euwallaceae was isolated without any signs of reproduction; A "nonattacked tree" referred to those where intact adult tree species were observed in the vicinity of attacked trees, observed on at least two separate sites.

the eight examined botanical families is displayed in Table 5. The highest percentage of tree species suitable for reproduction was obtained for Sapindaceae and Salicaceae, whereas the lowest percentage of tree species belonging to this category was within the Rosaceae, Myrtaceae, and Magnoliaceae. With regards to percentage of attacked tree species, in Fagaceae, Magnoliaceae and Malvaceae more than $90 \%$ of the tree species were included, whereas the lowest percentage of attacked tree species was recorded for Myrtaceae and Rosaceae, 25.6 and $64.0 \%$, respectively.

Figure 1 displays a cluster analysis of the tested botanical families based on the proportion of the three tree categories as compared with the schematic phylogenetic tree of these families, based on analysis made by Soltis et al. (2011). These authors constructed a 17-gene data set for 640 species representing 330 families using genes from the nuclear, plastid, and mitochondrial genomes. While the tested families were grouped according to their proportional tree categories, the cluster is dissimilar to the phylogenetic relationship (as suggested by Soltis et al., 2011).

\section{Genus Level Examination}

Among the 28 possible combinations of eight examined genera, 13 did not indicate significant differences within any of the three species categories (Table 6). The genera Acer, Quercus, and Acacia displayed the highest percentage within the "reproductive host" category, with the former significantly different from all seven of the studied genera; none of the examined 20 Eucalyptus spp. were suitable for PSHB reproduction (Table 7). However, concerning the percentage of affected trees (combination of species of "reproductive hosts" and "non-reproductive hosts"), we found that all Brachychiton and Erythrina were attacked; while on the other extreme were the Eucalyptus spp. with the lowest percentages of attacked tree species (Table 7).

In Figure 2 the cluster analyses of the tested botanical genera was performed in an identical manner to that done at the family level. The tested genera were grouped according to their proportional tree categories of the relevant tested species. One cluster included Acer and Quercus displaying the highest percentage of "reproductive host" category, along with Eucalyptus with the highest percentage of non-attacked tree category. The other group included the other examined genera with similar percentages of trees of from each category (Table 6). The overall clustering is dissimilar to the phylogenetic pattern (as derived from Soltis et al., 2011).

\section{DISCUSSION}

Attraction to a wide host range by the PSHB was well demonstrated in the present study and in others (Eskalen et al., 2013; Mendel et al., 2017; Gomez et al., 2019b). Similarly, a wide host range was recorded for the two other Euwallacea spp. of the fornicatus complex, E. perbrevis (= TSHB) and E. kuroshio (= KSHB) (Boland, 2016; Owens et al., 2018; Carrillo et al., 2019; Boland and Uyeda, 2020) as well as for Euwallacea similis (Browne, 1961). Wide and diverse host range characterizes many other members of the tribe Xyleborini. For example, Horn and Horn (2006) found that Xylosandrus crassiusculus reproduced on 124 host species of 48 families, including distinct taxa such as pine, cocoa, coffee, mahogany, rubber, tea, and teak. Many other examples demonstrating the wide host range of Xyleborini are mentioned in the introduction section (Schedl, 1963; Ngoan et al., 1976; Beaver, 1977, 1979; Kirkendall, 1983; Weber and McPherson, 1983; Atkinson et al., 1990; Wood and Bright, 1992; Rabaglia et al., 2006; Hulcr et al., 2007; Owens et al., 2018; CABI, 2020). Kuhnholz et al. (2001) raised the question of how ambrosia beetles became capable of attacking living trees that appear to be fully resistant. These authors suggested that if the introduced beetle or its tree host beetle or the host itself is introduced to a new location, lack of coevolution with the beetle imparts the potential to become more aggressive than toward 
TABLE 4 | Comparison of \% tree species of each category between eight botanical families.

\begin{tabular}{|c|c|c|c|c|c|c|c|c|}
\hline & Fagaceae & Magnoliaceae & Malvaceae & Myrtaceae & Rosaceae & Salicaceae & Sapindaceae & Families \\
\hline \multicolumn{9}{|c|}{ Tree Categories } \\
\hline A attacked & $0.0011^{*}$ & 0.23 & 0.74 & $<0.0001$ & 0.19 & 0.0010 & 0.0008 & Fabaceae \\
\hline N non-host & 0.0169 & 0.97 & 0.81 & $<0.0001$ & 0.0005 & 0.08 & 0.38 & \\
\hline $\mathrm{R}$ reproductive & 0.06 & 0.17 & 0.58 & 0.06 & $-^{\star \star}$ & 0.0108 & 0.0016 & \\
\hline A attacked & & 0.0012 & 0.0117 & $0.0236^{a}$ & 0.20 & 0.47 & 0.54 & Fagaceae \\
\hline N non-host & & 0.09 & 0.17 & $<0.0001$ & 0.20 & 0.83 & 0.34 & \\
\hline $\mathrm{R}$ reproductive & & $0.0199^{a}$ & 0.09 & 0.0079 & - & 0.35 & 0.17 & \\
\hline A attacked & & & 0.48 & $<0.0001$ & $0.0493^{a}$ & 0.0006 & 0.0006 & Magnoliaceae \\
\hline N non-host & & & 0.83 & $<0.0001$ & 0.0126 & 0.18 & 0.48 & \\
\hline $\mathrm{R}$ reproductive & & & 0.48 & 0.44 & - & 0.0052 & 0.0019 & \\
\hline A attacked & & & & $<0.0001$ & 0.21 & 0.0054 & 0.0055 & Malvaceae \\
\hline N non-host & & & & $<0.0001$ & $0.0275^{a}$ & 0.28 & 0.64 & \\
\hline $\mathrm{R}$ reproductive & & & & 0.16 & - & $0.0243^{a}$ & 0.0092 & \\
\hline A attacked & & & & & 0.0016 & 0.22 & 0.15 & \\
\hline N non-host & & & & & 0.0031 & 0.0002 & $<0.0001$ & Myrtaceae \\
\hline $\mathrm{R}$ reproductive & & & & & - & 0.0024 & 0.0011 & \\
\hline A attacked & & & & & & 0.08 & 0.09 & Rosaceae \\
\hline N non-host & & & & & & 0.21 & 0.06 & \\
\hline $\mathrm{R}$ reproductive & & & & & & - & - & \\
\hline A attacked & & & & & & & 0.89 & Salicaceae \\
\hline N non-host & & & & & & & 0.51 & \\
\hline $\mathrm{R}$ reproductive & & & & & & & 0.73 & \\
\hline
\end{tabular}

Effect Likelihood Ratio Tests (probability of $\chi^{2}, n=1$ ).

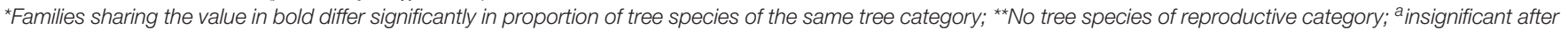
being subjected to Bonferroni correction.

its native host tree. Current analyses of the host range of the PSHB in Israel and California indicate that both native and exotic tree species for both areas are attacked and many among them successfully allowed beetle reproduction and associated fungal colonization; the indigenous tree genera attacked by the beetle are the same in both locations. While in California the PSHB killed more native trees than ornamental (planted out of their native habitats) ones (Coleman et al., 2013), in Israel, the situation is to the contrary (Mendel et al., 2017). Trees of the few genera, such as Acer and Platanus, were frequently attacked and killed in California and Israel but also in Southern China (Li et al., 2015). Although Ficus microcarpa was reported as a reproductive host in China (Coleman et al., 2019), attack of this tree was never observed in Israel or California, despite high occurrence of this ornamental species in both locations.

In the presumed natural range of the PSHB and the two other members of the Euwallacea fornicatus complex, attacks on live trees were reported on exotic tree species (Kalshoven, 1958; Walgama, 2012; Stouthamer, 2014). Kovach and Gorsuch (1985) suggested that most native ambrosia beetles found in peach orchards in South Carolina are more a symptom of other stress factors although the invasive species displayed aggressive behavior toward young "healthy looking" trees. However, the borderline between secondary and primary attack is not always clear; Euwallacea destruens native in Java attacks fast-growing teak trees in plantations and therefore is considered a primary pest of this native tree species (Kalshoven, 1981).

Two significant factors may define the process that determines host range of the PSHB (and other Xyleborini), host location

TABLE 5 | Comparison of occurrences of tree species suitable for reproduction and all attacked tree species of the eight examined botanical families.

\begin{tabular}{lccc}
\hline Family & $\begin{array}{c}\text { Number of } \\
\text { examined tree } \\
\text { species }\end{array}$ & $\begin{array}{c}\text { \% tree species } \\
\text { suitable for } \\
\text { reproduction }\end{array}$ & $\begin{array}{c}\% \text { all affected tree } \\
\text { species; suitable for } \\
\text { reproduction + attacked } \\
\text { alone }\end{array}$ \\
\hline Fabaceae & 92 & $16.5 \mathrm{bc}^{\star}$ & $93.4 \mathrm{a}$ \\
Fagaceae & 41 & $30.9 \mathrm{ab}$ & $78.6 \mathrm{bc}$ \\
Magnoliaceae & 31 & $6.4 \mathrm{c}$ & $93.5 \mathrm{a}$ \\
Malvaceae & 26 & $12.0 \mathrm{bc}$ & $92.0 \mathrm{ab}$ \\
Myrtaceae & 39 & $2.6 \mathrm{f}$ & $25.6 \mathrm{~d}$ \\
Rosaceae & 25 & $0 \mathrm{c}$ & $64.0 \mathrm{c}$ \\
Salicaceae & 21 & $42.7 \mathrm{a}$ & $81.0 \mathrm{abc}$ \\
Sapindaceae & 25 & $48.0 \mathrm{a}$ & $88.0 \mathrm{abc}$ \\
\hline
\end{tabular}

*Means sharing the same letter do not significantly differ (probability of $\times 2$, $n=1$ ). Normal approximations used for ratio confidence limits effects: Tests and confidence intervals on odds ratios are Wald based. 


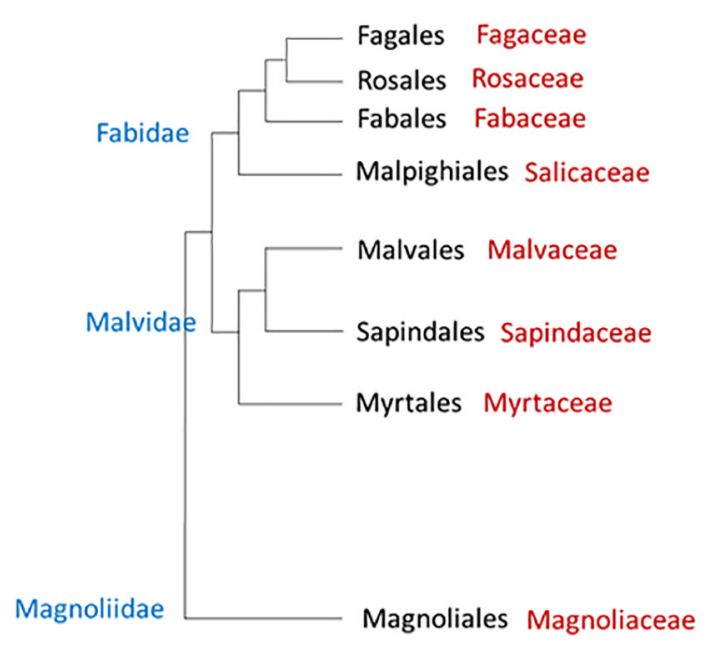

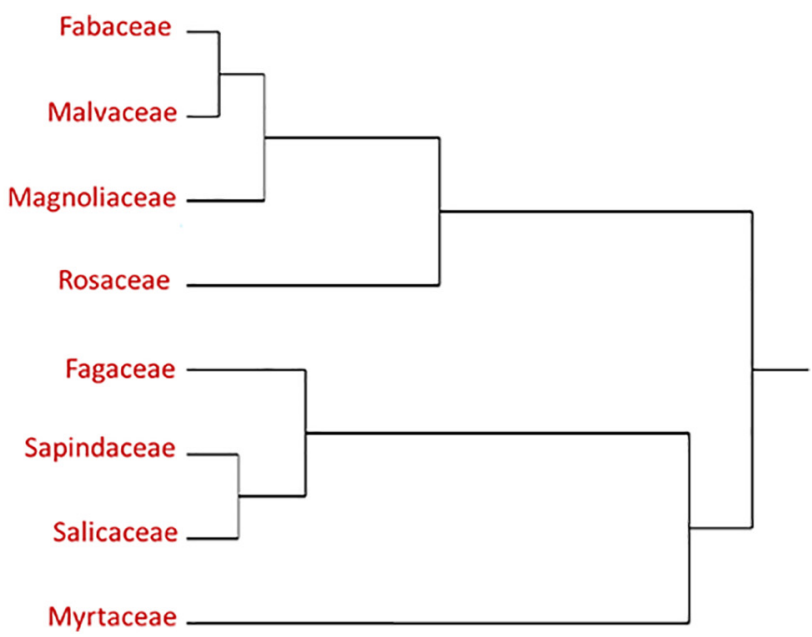

Myrtaceae

FIGURE 1 | Hierarchical clustering dendrogram of eight botanical families based on three susceptibility categories of tree species to PSHB (right, based on Table 4); as compared with phylogenetic tree of these families [left, according to Soltis et al. (2011)].

and acceptance, and host suitability for reproduction. All three above mentioned Euwallacea spp. of the fornicatus complex are not attracted to ethanol as opposed to many other members of the Xyleborini tribe (Ranger et al., 2018; Rabaglia et al., 2019; Chen et al., 2021, Mendel and Freeman unpublished data). However, it may be important to note that $F$. euwallaceae was neither facilitated nor compromised by ethanol up to $2 \%$ relative to the control (Lehenberger et al., 2021). These authors indicated that F. euwallaceae can tolerate ethanol, which is already known for the genus Fusarium. Considering the wide host range of the PSHB, initial host detection and selection may be modulated by different types of blends of volatiles typical to each of the hundreds of tree species that are attacked by the beetle. Similarly, Owens et al. (2018) suggested that TSHB might respond to different chemical cues to locate tree species suitable for breeding. Effective baits for the PSHB, TSHB, and KSHB are two natural compounds initially unrelated to these beetles, alpha-copaene and quercivorol (Dodge et al., 2017; Kendra et al., 2017; Mendel et al., 2017). The alpha-copaene is a sesquiterpenoid that was isolated in 1914 from the neotropical tree Copaifera langsdorffi (Kapadia et al., 1963); whereas quercivorol was identified as an aggregation pheromone component of the oak ambrosia beetle Platypus quercivorus (Kashiwagi et al., 2006). This apparent random accordance is still unexplained and the attraction to such different compounds suggests that predicting the attraction of PSHB to a certain tree species is still an unresolved challenge. Attraction of the PSHB to suitable host trees is intensified by previous conspecific colonization (Mendel et al., 2017). Hulcr et al. (2011) proved that X. glabratus, X. ferrugineus, and Xylosandrus crassiusculus were attracted to volatiles produced by their own symbiotic fungi, in the case of the former species also a cross attraction was demonstrated. These authors also suggested synergy of fungal produced volatiles with those of their host trees.

Attacks by the PSHB were observed on approximately $70 \%$ of the examined tree species in the present study. Since species of the "non-attacked host" category occurred in the vicinity of attacked tree species we may assume that the beetle was not attracted or even repelled by the tree volatiles or the tree was not "accepted" as a suitable host due to a deterrent effect during the initial boring into the cortex. It appears that under high infestation of the PSHB populations, the variety of attacked tree species is high, including many host species that apparently are not suitable for reproduction (Eskalen et al., 2013; Mendel et al., 2017; Coleman et al., 2019). Among the 407 attacked tree species observed in the present study, approximately $20 \%$ were apparently suitable for beetle reproduction.

Although the mechanism of initial attraction of the PSHB to a certain tree species is still unknown, there is little doubt that the PSHB is initially attracted to trees but probably not to ethanol, as opposed to many other ambrosia beetles. Ethanol is a key kairomone in attraction of Platypodinae (Graham, 1968; Moeck, 1970; Elliott et al., 2007) and ambrosia beetles among the Scolytinae (Ranger et al., 2015; Rabaglia et al., 2019). Ranger et al. (2018) demonstrated that ambrosia beetles rely on ethanol for host tree colonization since it promotes the growth of their fungal gardens while inhibiting the growth of "weedy" fungal competitors. Aggressive ambrosia beetles that colonize live trees barely respond to ethanol (Rabaglia et al., 2019).

Figure 3 displays a theoretical model suggesting the different possibility of potential tree species becoming attractive or nonattractive to PSHB attack (but may not necessarily end in successful reproduction). In PSHB native habitats, indigenous tree species are expected to become attractive to the beetle following stress conditions. However, some stressed tree species may lack the volatile combinations that induce attraction, or even produce compounds that may repel the beetle. Exotic tree species in both PSHB native and invasive areas, as well as native tree species in the invasive areas, display the same pattern of relationship as indigenous tree species in PSHB native locations. However, other exotic tree species in both PSHB native and invasive habitats as well as indigenous tree species in PSHB invasive areas are attractive to the beetle without any significant 
TABLE 6 | Comparison between of \% tree species of each category eight botanical genera.

\begin{tabular}{|c|c|c|c|c|c|c|c|c|}
\hline & Acer & Brachychiton & Camellia & Erythrina & Eucalyptus & Magnolia & Quercus & Genera \\
\hline \multicolumn{9}{|l|}{ Tree categories } \\
\hline A non-reproductive & $0.0204^{\star}$ & 0.32 & 0.67 & 0.42 & $0.0294^{a}$ & 0.29 & 0.13 & Acacia \\
\hline N non-host & 0.96 & 0.99 & 0.55 & 0.99 & 0.0041 & 1 & 0.23 & \\
\hline $\mathrm{R}$ reproductive & 0.0207 & 0.52 & 0.30 & 0.68 & $--^{\star \star}$ & 0.20 & 0.51 & \\
\hline A non-reproductive & & 0.0100 & 0.0085 & 0.0051 & 0.69 & 0.0005 & 0.17 & Acer \\
\hline N non-host & & 0.99 & 0.59 & 0.99 & 0.0052 & 0.95 & 0.26 & \\
\hline $\mathrm{R}$ reproductive & & 0.0195 & 0.0061 & 0.0119 & - & 0.0005 & $0.0249^{a}$ & \\
\hline A non-reproductive & & & 0.51 & 0.75 & 0.0146 & 0.78 & $0.0463^{a}$ & Brachychiton \\
\hline N non-host & & & 0.99 & 1 & 0.99 & 0.99 & 0.99 & \\
\hline $\mathrm{R}$ reproductive & & & 0.77 & 0.75 & - & 0.73 & 0.24 & \\
\hline A non-reproductive & & & & 0.68 & 0.0119 & 0.56 & 0.06 & Camellia \\
\hline N non-host & & & & 0.99 & 0.0053 & 0.46 & 0.529 & \\
\hline $\mathrm{R}$ reproductive & & & & 0.51 & - & 1 & 0.119 & \\
\hline A non-reproductive & & & & & 0.0071 & 0.93 & $0.0308^{a}$ & Erythrina \\
\hline N non-host & & & & & 0.99 & 0.99 & 0.999 & \\
\hline $\mathrm{R}$ reproductive & & & & & - & 0.42 & 0.29 & \\
\hline A non-reproductive & & & & & & 0.0005 & 0.28 & Eucalyptus \\
\hline N non-host & & & & & & 0.0002 & 0.0016 & \\
\hline $\mathrm{R}$ reproductive & & & & & & & 0.99 & \\
\hline A non-reproductive & & & & & & & 0.0029 & Magnolia \\
\hline N non-host & & & & & & & 0.11 & \\
\hline $\mathrm{R}$ reproductive & & & & & & & $0.0326^{\mathrm{a}}$ & \\
\hline
\end{tabular}

Effect Likelihood Ratio Tests (probability of $\chi^{2}, n=1$ ).

${ }^{*}$ Genera sharing value in bold differ significantly in proportion of tree species of the same tree category.

${ }^{* *}$ No tree species of reproductive category.

a insignificant after being subjected to Bonferroni correction.

stress. Based on our observation in Israel and in California it appears that stressed trees among the latter group lose their attraction to the PSHB.

There is no doubt that the PSHB attacks may cause tree mortality on certain host trees (Hulcr and Dunn, 2011; Mendel et al., 2017; Paap et al., 2018; Coleman et al., 2019). However, the concept of attacks on "healthy" trees is often debated in the literature, as trees that appear healthy may have been previously exposed to some stress (Grousset et al., 2020). Keler (1956) defined primary insects as "those which prefer completely healthy plants in full vigor"; based on this definition, Rudinsky (1962) suggested that most species of bark and ambrosia beetles must be considered secondary insects. In the case of ambrosia beetles of the Platypodinae, Kuhnholz et al. (2001) distinguished between primary and secondary ambrosia beetles and discussed the factors that may be responsible for an increasing prevalence of attack by secondary ambrosia beetles on living trees. The PSHB and its complex members cannot fall into primary or secondary categories since these species attack both weakened and healthy tree species. Coleman et al. (2019) suggested that tree mortality rates caused by the PSHB among hardwood species were low even though infestation levels by both beetles were exceptionally high. This may be related to colonization of weakened specimens of certain tree species whereas healthy trees can tolerate the attack.

A typical ecological question asked is why tree species related to one genetic group are more susceptible to attack and suitable for reproduction of the PSHB than those related to another genetic group? And, how to explain the distinct susceptibly among member of each taxonomic level, family and genus as demonstrated by the present findings, as well as the extreme differences between genotypes of the same species which was well demonstrated for avocado (Persea americana) cultivars (Jones and Paine, 2017; Mendel et al., 2017; Freeman et al., 2019). The question is how to relate the confounding effects of different genetic groups of trees. The clustered taxa of the selected families and genera we compared indicated that differences are apparently independent of their phylogenies. This discordance between host tree phylogeny and susceptibility to the PSHB, as shown in Figures 1, 2, indicates that the trait 
TABLE 7 | Comparison of occurrences of tree species suitable for reproduction and all attacked tree species in each of the eight examined botanical genera.

\begin{tabular}{cccc}
\hline Genera & $\begin{array}{c}\text { Number of } \\
\text { examined tree } \\
\text { species }\end{array}$ & $\begin{array}{c}\text { \% tree species } \\
\text { suitable for } \\
\text { reproduction }\end{array}$ & $\begin{array}{c}\% \text { affected tree species } \\
\text { (suitable for } \\
\text { reproduction + non- } \\
\text { reproductive) }\end{array}$ \\
\hline
\end{tabular}

$\begin{array}{lccc}\text { Acacia } & 15 & 20.0 \mathrm{bc}^{*} & 93.3 \mathrm{ab} \\ \text { Acer } & 14 & 64.3 \mathrm{a} & 92.9 \mathrm{ab} \\ \text { Brachychiton } & 10 & 10.0 \mathrm{bcd} & 100 \mathrm{a} \\ \text { Camellia } & 15 & 6.7 \mathrm{bcd} & 86.7 \mathrm{ab} \\ \text { Erythrina } & 14 & 14.3 \mathrm{bcd} & 100 \mathrm{a} \\ \text { Eucalyptus } & 20 & 0.0 \mathrm{~d} & 35 \mathrm{c} \\ \text { Magnolia } & 30 & 6.7 \mathrm{~cd} & 93.3 \mathrm{ab} \\ \text { Quercus } & 38 & 28.9 \mathrm{~b} & 78.9 \mathrm{~b}\end{array}$

*Means sharing the same letter do not significantly differ (probability of $\times 2$, $n=1)$. Normal approximations used for ratio confidence limits effects: Tests and confidence intervals on odds ratios are Wald based.

correlation of susceptibility of different tree species to the PSHB are the results of convergent evolution and not of a common descent. However, Lynch et al. (2020) recently demonstrated a strong phylogenetic signal in the relative effects of PSHB and KSHB and their associated fungal symbionts on tree host species in California and South Africa, demonstrating that the severity of multi-host pest impacts in plants can be predicted by host evolutionary relationships. Patterns in the signal indicate that there are several ways to be susceptible, but susceptibility clusters within phylogenetic groups and this clumping becomes more restricted with more impactful interactions. These authors show that the "reproductive" host range was phylogenetically restricted than "non-reproductive" hosts by $62 \mathrm{Myr}$, and those with devastating impacts were the most constrained, narrower by $107 \mathrm{Myr}$.

Among 407 attacked tree species by the PSHB only approximately $20 \%$ were found suitable for reproduction. Upon attack, the beetle enters the cortex to reach the sapwood. Bark is the first line of defense against wood decay organisms such as fungi and bacteria (Franceschi et al., 2005; Alexander, 2010) and by wounding the bark the beetle allows the invasion of its fungal symbionts. Mechanical wounding is necessary but not sufficient to trigger the full response activated by insects and the damage inflicted by invading microorganisms may trigger the full response by the plant (Maffei et al., 2007). The external response to beetle penetration is typical to tree taxa and the specific wounding response. For example, the attacks on persimmon trees result in secretion of a black viscous gum; species of Platanus and Quercus respond by oozing out watery transparent gum; while the typical response of avocado is exudation of a white sugar (persitol), which is somehow different from a similar exudation in response to physical wounding (Eskalen et al., 2012, 2013; Mendel et al., 2017). Boland and Woodward (2021) demonstrated that bark thickness influences KSHB attack densities and attack locations and therefore affects KSHB impacts. It is suggested that both mechanical wounding by the beetle and invasion by its fungal symbiont $F$. euwallaceae trigger induced defense responses of the tree.

The above-described symptoms induced by the PSHB attack are conspicuous in cases of both "non-reproductive host" and "reproductive host" categories. It may be important to note that there are marked differences in the performance of the beetles among different host species suitable for reproduction (Mendel et al., 2017; Freeman et al., 2019). For example, while Acer negundo is defined as a highly suitable host for reproduction of the PSHB (Eskalen et al., 2013; Mendel et al., 2017; Paap et al., 2018; Coleman et al., 2019), native Acer obtusifolium in Israel usually displays reproduction hindrance and offspring development was rarely observed (Mendel and Freeman unpublished data). In the case of avocado, several cultivars seldomly allowed reproduction of the beetle, even in the case of Hass cultivar, usually only secondary and tertiary

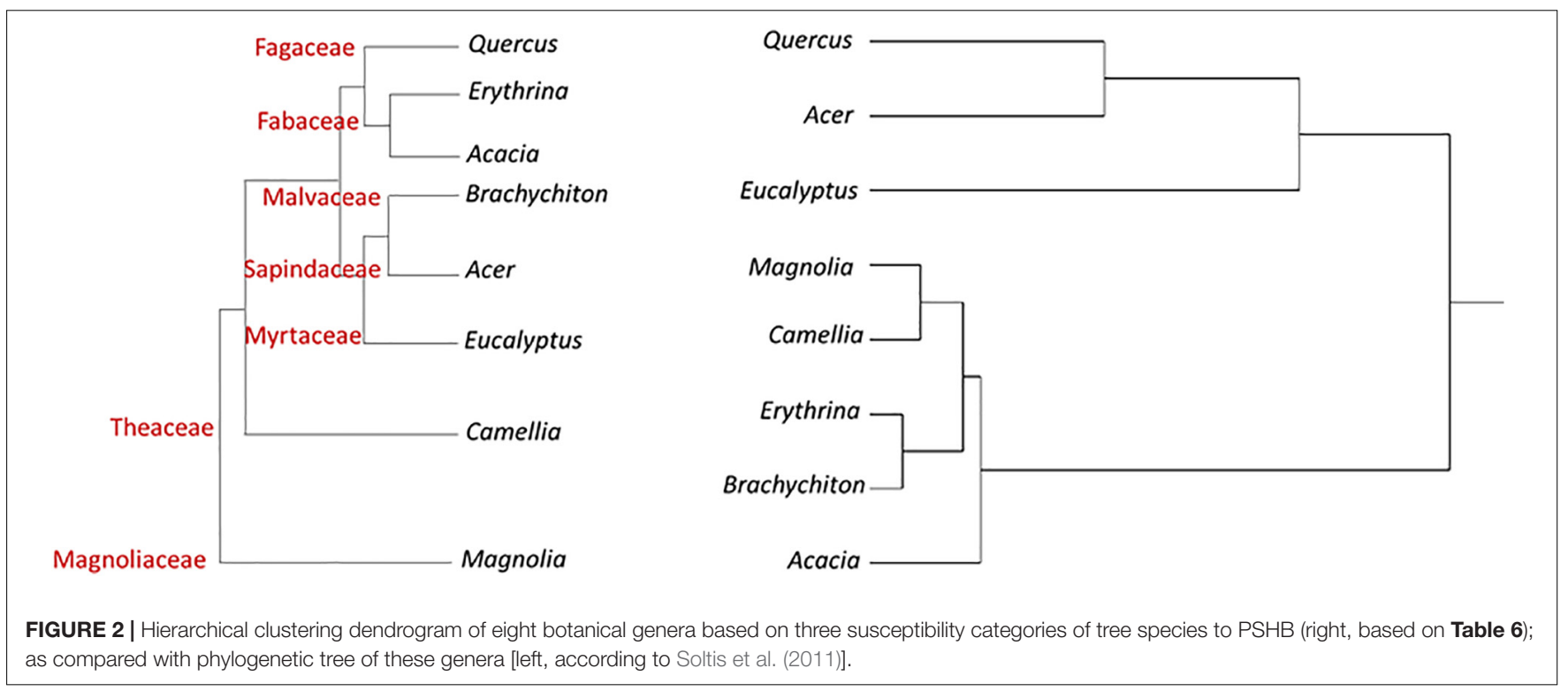




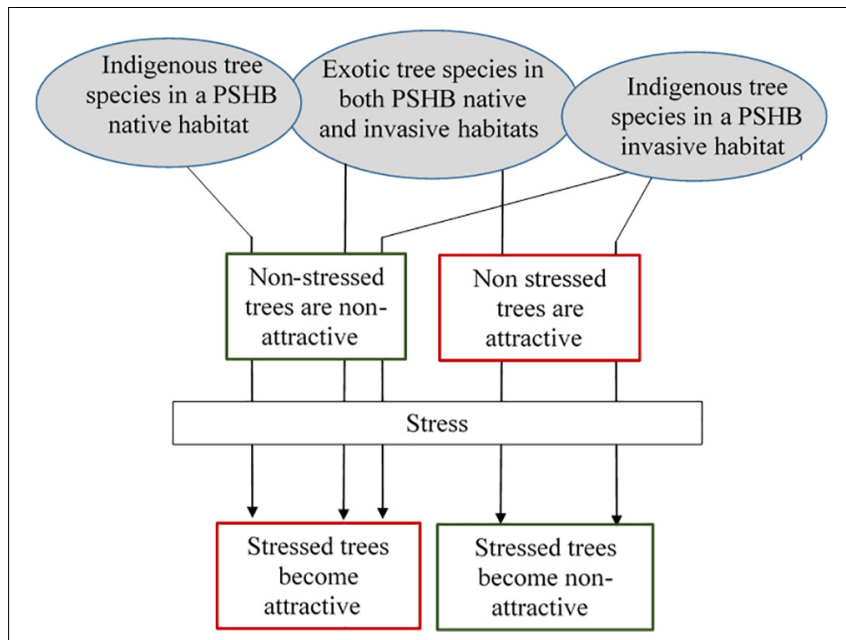

FIGURE 3 | A theoretical model suggesting the probability of a tree species becoming attractive or non-attractive to PSHB attack.

branches permitted reproduction which often occurred on "reattacked" branches, viz., after previously unsuccessful attacks (Mendel et al., 2017). Unlike the resin flow which serves in pitching out adult bark beetles attacking pine trees almost immediately or in a matter of hours as a reaction to the beetle injury (Berryman, 1972; Smith, 1972), conspicuous sugary exudation in response to the PSHB penetration into avocado woody branches was observed 3-10 days thereafter (Mendel and Freeman unpublished data). Therefore, the exudation obstruction is probably not the mechanism preventing successful colonization of the beetle in hosts belonging to the "attacktree" category.

In the present study, species across the "non-reproductive host" category were recognized by the typical injury response and in most cases also by isolation of F. euwallaceae, introduced by the beetle. The fundamental question concerns the obstacles responsible for reproductive impediment in many of these cases. However, similar obstacles may play a role in the quality of reproductive performance in the case of species belonging to the "reproductive host" category.

It is suggested that the beetle reproduction success rate over a wide host range, as well as the long list of species belonging to the "non-reproductive host" category, is the outcome of interaction between Fusarium euwallaceae and sapwood of the attacked tree. F. euwallaceae was defined as a pseudopathogen since typical wilting of the damaged tree occurs only in association with the degree of beetle infestation within the wood (Freeman et al., 2019). Fungal pathogens may be classified as biotrophs, necrotrophs or hemi-biotrophs, fungi of the latter types display both biotrophic and necrotrophic features (Lee and Rose, 2010). Pathogens may switch their strategy of infection from biotrophy to necrotrophy (Chowdhury et al., 2017). Fusarium euwallaceae is a wound pathogen that develops on gallery walls excavated by the beetle. It may also be characterized as a weak hemibiotrophic pathogen as it develops at the onset of colonization on live sapwood tissue, but may remain as an endophyte in the case of unsuccessful attack or artificial inoculation into healthy sapwood. In addition, it does not progress more than a few $\mathrm{mm}$ beyond the inoculated tunnel wall at infection points and is maintained in the dying tissue (Freeman et al., 2019). Weakening of xylem tissue in close proximity of the galleries permits development of the two other fungal symbionts of the PSHB that may survive in the killed dead sapwood for 1 year or even longer (Mendel et al., 2017). It appears that G. euwallacea that serves as a food source at the immature beetle stages may thrive in the galleries only after successful development of F. euwallacea (Freeman et al., 2019; Carrillo et al., 2020). Fusarium euwallacea, similar to many xylem fungi, displays a wide host range in contrast to other fungal pathogens of the same group, such as $F$. mangiferae that colonizes bud tissues of the tree (Freeman et al., 2012). The defense mechanism that constrains pathogen development in the sapwood of many tree species includes constitutive and induced inhibitory compounds, but also cell wall alterations, and occlusion of xylem elements, as well as constitutive and induced micro-environmental conditions in this woody tissue (Beckman, 1987; Gordon and Reynolds, 2017). The trees sense the injured tissue and induce defense responses activated by pathogen infection (Yamada, 2001; Savatin et al., 2014).

A theoretical model proposing the process leading to a dichotomist situation categorizing a host species of the PSHB as "non-reproductive host" or "reproductive host" is demonstrated in Figure 4. The model suggests that a tree selected by the PSHB may belong to one of three groups, (1) those in which F. euwallacea is unable to develop, (2) those tree species that slow the development of the fungus, and (3) those which

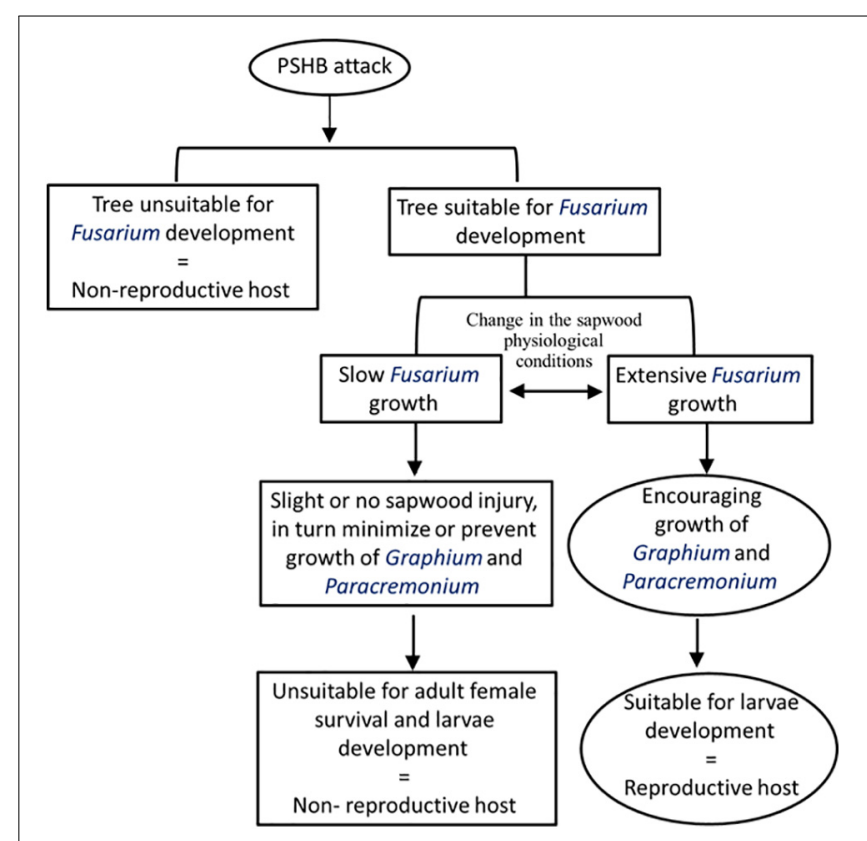

FIGURE 4 | A theoretical model explaining the relationships between the performance of Fusarium euwallaceae and the suitability of host tree species for $\mathrm{PSHB}$ reproduction. 
enable F. euwallacea to thrive. Hence, the host range suitable for the beetle reproduction is determined by development of F. euwallacea. The ambrosia Fusarium clade currently comprises 19 phylogenetically distinct species, most of which are known to be farmed by Euwallacea congeneric females (Aoki et al., 2019). Carrillo et al. (2019) reported that the sampled PSHB in Taiwan carried Fusarium kuroshium, which is associated with the KSHB in California, whereas the TSHB was found to be associated with six different Fusarium spp. in different native and invasive habitats (O'Donnell et al., 2015; Aoki et al., 2019; Lynn et al., 2020). A genetic variation e demonstrated for the fungal symbiont of $X$. glabratus was found in native populations of the beetle in Taiwan, Japan and the United States (Wuest et al., 2017). It has been suggested that members of the Euwallacea fornicatus species complex (Carrillo et al., 2019) and also Xyleborus spp. (Kostovcik et al., 2015) are more promiscuous in native areas, while in invaded areas this association is apparently limited and species specific. Carrillo et al. (2020) showed that brood of the PSHB and KSHB developed well on their reciprocal fungal symbionts (including Graphium spp.), although Freeman et al. (2012) demonstrated that the PSHB brood could not develop on Fusarium ambrosium. However, both the PSHB and KSHB are more genetically related than the TSHB (Stouthamer et al., 2017) and similar relationships were revealed between F. euwallaceae and F. kuroshium. Both the latter fungi are more closely genetically related than the six Fusarium spp. symbionts of the TSHB including F. ambrosium, based on molecular sequence similarity (Aoki et al., 2019). Therefore, it is plausible to assume that different natural populations of each species among the Euwallacea fornicatus species complex may display a varied host species range of the "reproductive host" category that may be dependent on recognition of the Fusarium symbiotic species. Our findings suggest that in general the PSHB does not distinguish between host species of the "non-reproductive host" and "reproductive host" categories. However, it appears that host species belonging to one category may be reassigned to another if the PSHB carries a different Fusarium symbiont or if site conditions differ in the attacked locations.

\section{DATA AVAILABILITY STATEMENT}

The datasets presented in this study can be found in online repositories. The names of the repository/repositories and

\section{REFERENCES}

Alexander, H. (2010). Disease in natural plant populations, communities, and ecosystems: insights into ecological and evolutionary processes. Plant Dis. 94, 492-503. doi: 10.1094/pdis-94-5-0492

Alfaro, R., Humble, L., Gonzalez, P., Villaverde, R., and Allegro, G. (2007). The threat of the ambrosia beetle Megaplatypus mutatus (Chapuis) (=Platypus mutatus Chapuis) to world poplar resources. Forestry 80, 471-479. doi: 10.1093/ forestry/cpm029

Anon. (2014). PSHB Exploration in Vietnam. Available online at: https: //www.californiaavocadogrowers.com/cultural-management-library/pshbexploration-vietnam (accessed September 2020).

Aoki, T., Kasson, J., Freeman, S., Geiser, D., Geering, A., and O’Donnell, K. (2019). Three novel Ambrosia Fusarium Clade species producing clavate macroconidia accession number(s) can be found in the article/Supplementary Material.

\section{AUTHOR CONTRIBUTIONS}

ZM: conceptualization, methodology, investigation, writing of manuscript, and raising of partial funding. $\mathrm{AE}$ and SL: investigation and editing of the manuscript. AP and MM: assistance with technical field and lab experiments. SF: investigation, writing of manuscript, and raising of partial funding. All authors contributed to the article and approved the submitted version.

\section{FUNDING}

This research was partially funded by grants from the Chief Scientist of the Israeli Ministry of Agriculture and Rural Development (Nos. 131-1679 and 131-1834), from Forest Department KKL (No. 01-12-100-02) and from the Israeli Avocado Growers' Association.

\section{ACKNOWLEDGMENTS}

We are grateful to Dr. Hillary Voet, from the Robert H. Smith Faculty of Agriculture, Food and Environment at the Hebrew University of Jerusalem, for assistance with statistical analyses of the data; and to Dr. Robert Rabaglia, Forest Service, State and Private Forestry, Forest Health Protection, Washington Office, for its useful comments on an early draft. We appreciate the valuable suggestions of three reviewers that helped to improve the script. We thank avocado growers, gardeners, landscape managers, and botanical gardens specialists who shared valuable information regarding infested host trees on their properties and allowed us to remove plant materials for the present study.

\section{SUPPLEMENTARY MATERIAL}

The Supplementary Material for this article can be found online at: https://www.frontiersin.org/articles/10.3389/ffgc.2021. 654702/full\#supplementary-material

known (F. floridanum and F. obliquiseptatum) or predicted (F. tuaranense) to be farmed by Euwallacea spp. (Coleoptera: scolytinae) on woody hosts. Mycologia 111, 919-935. doi: 10.1080/00275514.2019.1647074

Atkinson, T., and Equihua-Martinez, A. (1986). Biology of bark and ambrosia beetles (Coleoptera: scolytidae and Platypodidae) of a tropical rainforest in southeastern Mexico with an annotated checklist of species. Ann. Entomol. Soc. Am. 79, 414-423. doi: 10.1093/aesa/79.3.414

Atkinson, T., Foltzm, J., Wilkinson, R., and Mizell, R. (1988). Granulate Ambrosia Beetle, Xylosandrus crassiusculus (Motschulsky) (Insecta: Coleoptera: Curculionidae: Scolytinae). EDIS 2011. Available online at: https://journals.flvc. org/edis/article/view/119233 (accessed May 2019).

Atkinson, T., Rabaglia, R., and Bright, D. (1990). Newly detected exotic species of Xyleborus (Coleoptera: scolytidae) with a revised key to species in eastern North America. Can. Entomol. 122, 93-104. doi: 10.4039/ent12293-1 
Baker, J., and Norris, D. (1968). A complex of fungi mutualistically involved in the nutrition of the ambrosia beetle Xyleborus ferrugineus. J. Invertebr. Pathol. 11, 246-250. doi: 10.1016/0022-2011(68)90157-2

Beaver, R. (1977). Bark and ambrosia beetles in tropical forests. Proc. Symposium forest pests and diseases SE Asia, Bogor, Indonesia, Indonesia, 1976. Biotrop 2, $133-147$.

Beaver, R. (1979). Host specificity of temperate and tropical animals. Nature 281, 134-141.

Beckman, C. (1987). The Nature of Wilt Diseases of Plants. Saint Paul, MN: APS Press, 175 .

Berryman, A. (1972). Resistance of conifers to invasion by bark beetle-fungus associations. BioScience 22, 598-602. doi: 10.2307/1296291

Boland, J. (2016). The impact of an invasive ambrosia beetle on the riparian habitats of the Tijuana River Valley, California. PeerJ 4:e2141. doi: 10.7717/peerj.2141

Boland, J., and Uyeda, K. (2020). The Ecology and Management of the Kuroshio Shot Hole Borer in the Tijuana River Valley. 2019-20 (Year 5). Available online at: https://trnerr.org/wp-content/uploads/2020/05/KSHBTRValley2020.pdf (accessed November 2020).

Boland, J. M., and Woodward, D. L. (2021). Thick bark can protect trees from a severe ambrosia beetle attack. PeerJ 9:e10755. doi: 10.7717/peerj.10755

Browne, F. (1961). The biology of malayan scolytidae and platypodidae. Mal. For. Rec. 22, 1-255.

CABI (2020). Invasive Species Compendium. Wallingford: CAB International.

Carrillo, J., Dodge, C., Stouthamer, R., and Eskalen, A. (2020). Fungal symbionts of the polyphagous and Kuroshio shot hole borers (Coleoptera: scolytinae: Euwallacea spp.) in California can support both ambrosia beetle systems on artificial media. Symbiosis 80, 155-168. doi: 10.1007/s13199-019-00652-0

Carrillo, J., Rugman-Jones, P., Husein, D., Stajich, J., Kasson, M., Carrillo, D., et al. (2019). Members of the Euwallacea fornicatus species complex exhibit promiscuous mutualism with ambrosia fungi in Taiwan. Fungal Genet. Biol. 133:103269. doi: 10.1016/j.fgb.2019.103269

Chen, Y., Coleman, T., Ranger, C. M., and Seybold, S. (2021). Differential flight responses of two ambrosia beetles to ethanol as indicators of invasion biology: the case with Kuroshio shot hole borer (Euwallacea kuroshio) and fruit-tree pinhole borer (Xyleborinus saxesenii)*. Ecol. Entomol. 52, 243-259. doi: 10. 1111/een.13013

Chowdhury, S., Basu, A., and Kundu, S. (2017). Biotrophy-necrotrophy switch in pathogen evoke differential response in resistant and susceptible sesame involving multiple signaling pathways at diferent phases. Nat. Sci. Rep. 7:17251. doi: 10.1038/s41598-017-17248-7

Coleman, T., Eskalen, A., and Stouthamer, R. (2013). New Pest Complex in California: the Polyphagous Shot Hole Borer, Euwallacea sp., and Fusarium Dieback, Fusarium Euwallaceae. USDA Forest Service, Pest Alert, R5-PR-032, 4 November 2013. 5. Available online at: https://cisr.ucr.edu/pdf/pest_alert_pshb_ and_fd.pdf (accessed May 2019).

Coleman, T., Poloni, A., Chen, Y., Thu, P., Li, Q., and Sun, J. (2019). Hardwood injury and mortality associated with two shot hole borers, Euwallacea spp., in the invaded region of southern California, USA, and the native region of Southeast Asia. Ann. For. Sci. 76:61. doi: 10.1007/s13595-019-0847-6

Cooperband, M., Cosse, A., Jones, T., Carrillo, D., Cleary, K., and Canlas, I. (2017). Pheromones of three ambrosia beetles in the Euwallacea fornicatus species complex: ratios and preferences. PeerJ 5:3957.

Danthanarayana, W. (1968). The distribution and host-range of the shothole borer (Xyleborus fornicatus Eichh.) of tea. Tea Q. 39, 61-69.

Dodge, C., Coolidge, J., Cooperband, M., Cosse, A., Carrillo, D., and Stouthamer, R. (2017). Quercivorol as a lure for the polyphagous and Kuroshio shot hole borers, Euwallacea spp. nr. fornicatus (Coleoptera: scolytinae), vectors of Fusarium dieback. PeerJ 5:e3656. doi: 10.7717/peerj.3656

Elliott, H., Madden, J., and Bashford, R. (2007). The association of ethanol in the attack behaviour of the mountain pinhole borer Platypus subgranosus Schedl (Coleoptera: curculionidae: platypodinae). Aust. J. Entomol. 22, 299-302. doi: 10.1111/j.1440-6055.1983.tb02104.x

Eskalen, A., Gonzalez, A., Wang, D., Twizeyimana, M., Mayorquin, J., and Lynch, S. (2012). First report of a Fusarium sp. and its vector tea shot hole borer (Euwallacea fornicatus) causing Fusarium dieback on avocado in California. Plant Dis. 96:1070. doi: 10.1094/pdis-03-12-0276-pdn

Eskalen, A., Stouthamer, R., Lynch, S., Rugman-Jones, P., Gonzalez, A., and Thibault, T. (2013). Host range of Fusarium dieback and its ambrosia beetle
(Coleoptera: scolytinae) vector in southern California. Plant Dis. 97, 938-951. doi: 10.1094/PDIS-11-12-1026-RE

Farrell, B., Sesqueira, A., O’Meara, B., Normark, B., Chung, J., and Jordal, H. (2001). The evolution of agriculture in beetles (Curculionidae: scolytinae and Platypodinae(. Evolution 55, 2011-2027. doi: 10.1111/j.0014-3820.2001. tb01318.x

Fraedrich, S., Harrington, T., and Best, G. (2014). Xyleborus glabratus attacks and systemic colonization by Raffaelea lauricola associated with dieback of Cinnamomum camphora in the southeastern United States. Forest Pathol. 45, 60-70. doi: 10.1111/efp.12124

Franceschi, V., Krokene, P., Christiansen, E., and Krekling, T. (2005). Anatomical and chemical defenses of conifer bark against bark beetles and other pests. New Phytol. 167, 353-375. doi: 10.1111/j.1469-8137.2005.01436.x

Francke-Grosmann, H. (1967). "Ectosymbiosis in wood-inhabiting insects," in Symbiosis: Associations of Invertebrates, Birds, Ruminants and Other Biota, 2 Edn, ed. S. Henry (New York, NY: Academic Press), 141-206. doi: 10.1016/ b978-1-4832-2758-0.50010-2

Frankland, J. (1998). Fungal succession - unravelling the unpredictable. Mycol. Res. 102, 1-15. doi: 10.1017/s0953756297005364

Freeman, S., Miller, G., Protasov, A., Maymon, M., Elazar, David-Schwartz, R., et al. (2019). Aposymbiotic interactions of three ambrosia beetle fungi with avocado trees. Fungal Ecol. 39, 117-130. doi: 10.1016/j.funeco.2018.11.007

Freeman, S., Protasov, A., Sharon, M., Mohotti, K., Eliyahu, M., Okon-Levy, N., et al. (2012). Obligate feed requirement of Fusarium sp. nov., an avocado wilting agent, by the ambrosia beetle Euwallacea aff. fornicata. Symbiosis 58, 245-251. doi: 10.1007/s13199-013-0222-6

Gomez, D., Hulcr, J., and Carrillo, D. (2019a). Diagnosis and Management of the Invasive Shot Hole Borers Euwallacea fornicatus, E. kuroshio and E. perbrevis (Coleoptera: Curculionidae: Scolytinae). UF/IFAS Extension. Available online at: https://edis.ifas.ufl.edu (accessed June 2019).

Gomez, D., Lin, W., Gao, L., and Li, Y. (2019b). New host plant records for the Euwallacea fornicatus (Eichhoff) species complex (Coleoptera: curculionidae: scolytinae) across its natural and introduced distribution. J. Asia-Pacif. Entomol. 22, 338-340. doi: 10.1016/j.aspen.2019.01.013

Gordon, T. R., and Reynolds, G. J. (2017). Plasticity in plant-microbe interactions: a perspective based on the pitch canker pathosystem. Phytoparasitica 45, 1-8. doi: 10.1007/s12600-016-0558-6

Graham, K. (1968). Anaerobic induction of primary chemical attractancy for ambrosia beetles. Can. J. Zool. 46, 905-908. doi: 10.1139/z68-127

Grousset, F., Gregoire, J., Jactel, H., Battisti, A., Beloglavec, A., Hrasovec, B., et al. (2020). The risk of bark and ambrosia beetles associated with imported non-coniferous wood and potential horizontal phytosanitary measures. Forests 11:342. doi: $10.3390 /$ f1 1030342

Henin, J., and Versteirt, V. (2004). Abundance and distribution of Xylosandrus germanus (Blandford, 1894) (Coleoptera: scolytidae) in Belgium: new observations and an attempt to outline its range. J. Pest Sci. 77, 57-63. doi: 10.1007/s10340-003-0030-5

Horn, S., and Horn, G. (2006). New host record for the Asian ambrosia beetle, Xylosandrus crassiusculus (Wlotschulsky) (Coleoptera: curculionidae). Entomol. Sci. 41, 90-91. doi: 10.18474/0749-8004-41.1.90

Hulcr, J., and Dunn, R. R. (2011). The sudden emergence of pathogenicity in insect-fungus symbioses threatens naive forest ecosystems. Proc. Roy. Soc. B Sci. 278, 2866-2873. doi: 10.1098/rspb.2011.1130

Hulcr, J., Mann, R., and Stelinski, L. (2011). The scent of a partner: ambrosia beetles are attracted to volatiles from their fungal symbionts. J. Chem. Ecol. 37, 1374-1377. doi: 10.1007/s10886-011-0046-x

Hulcr, J., Mogia, M., Isua, B., and Novotny, V. (2007). Host specificity of ambrosia and bark beetles) Coleoptera: curculionidae: scolytinae and Platypodinae) in a New Guinea rainforest. Ecol. Entomol. 32, 762-772. doi: 10.1111/j.1365-2311. 2007.00939.x

Hulcr, J., and Stelinski, L. (2017). The ambrosia symbiosis: from evolutionary ecology to practical management. Annu. Rev. Entomol. 62, 285-303. doi: 10. 1146/annurev-ento-031616-035105

Inch, S., and Ploetz, R. (2012). Impact of laurel wilt, caused by Raffaelea lauricola, on xylem function in avocado. J. For. Pathol. 42, 239-245. doi: 10.1111/j.14390329.2011.00749.x

Inch, S., Ploetz, R., Blanchette, R., and Held, B. (2012). Histological and anatomical responses in avocado, Persea americana, induced by the vascular 
wilt pathogen, Raffaelea lauricola. Botany 90, 627-635. doi: 10.1139/b20 12-015

Jones, M., and Paine, T. (2017). Differences among avocado cultivars in susceptibility to polyphagous shot hole borer (Euwallacea sp.). Entomol. Exp. Appl. 163, 296-304. doi: 10.1111/eea.12577

Jordal, B., and Cognato, A. (2012). Molecular phylogeny of bark and ambrosia beetles reveals multiple origins of fungus farming during periods of global warming. BMC Evol. Biol. 12:133. doi: 10.1186/1471-214812-133

Jordal, B., Normark, B., and Farrell, B. (2000). Evolutionary radiation of an inbreeding haplodiploid beetle lineage. Biol. J. Linn. Soc. 71, 483-499. doi: 10.1111/j.1095-8312.2000.tb01270.x

Kalshoven, L. (1958). Studies on the biology of Indonesian Scolytoidea. 1. Xyleborus fornicatus Eichh. as a primary and secondary shot-hole borer in Java and Sumatra. Part 2. Entomol. Ber. (Amst.) 18, 185-190.

Kalshoven, L. (1981). Pest of Crops in Indonesia. Jakarta: Ichtiar Baru.

Kapadia, V., Nagasampagi, B., Naik, V., and Dev, S. (1963). Structure of mustakone and copaene. Tetrahedron Lett. 4, 1933-1939. doi: 10.1016/S0040-4039(01) 90945-1

Kashiwagi, T., Nakashima, T., Tebayashi, S., and Kim, C. (2006). Determination of the absolute configuration of quercivorol, (1S,4R)-p-menth-2-en-1-ol, an aggregation pheromone of the ambrosia beetle, Platypus quercivorus (Coleoptera: platypodidae). Biosci. Biotech. Bioch. 70, 2544-2546. doi: 10.1271/ bbb.60211

Kasson, M., O’Donnell, K., Rooney, A., Sink, S., and Ploetz, R. (2013). An inordinate fondness for Fusarium: phylogenetic diversity of fusaria cultivated by ambrosia beetles in the genus Euwallacea on avocado and other plant hosts. Fungal Genet. Biol. 56, 147-157. doi: 10.1016/j.fgb.2013.04.004

Keler, S. (1956). Entomologisches Worterbuch. AUA. Berlin: Akademie Verlag, 679.

Kendra, P., Montgomery, W., Niogret, J., Pena, J., Capinera, J., Brar, G., et al. (2011). Attraction of the redbay ambrosia beetle, Xyleborus glabratus, to avocado, lychee, and essential oil lures. J. Chem. Ecol. 37, 932-942. doi: 10.1007/ s10886-011-9998-0

Kendra, P., Owens, D., Montgomery, W., Narvaez, T., Bauchan, W., Schnell, E., et al. (2017). $\alpha$-Copaene is an attractant, synergistic with quercivorol, for improved detection of Euwallacea nr. fornicatus (Coleoptera: curculionidae: scolytinae). PLoS One 12:e0179416. doi: 10.1371/journal.pone.0179416

Keshavareddy, G., Verghese, A., and Kumar, H. (2008). Spatial distribution of the damage of shot hole borer (Coleoptera: scolytidae) on grapes. Curr. Biot. 2, 18-31.

Kimmerer, T., and Kozlowski, T. (1982). Ethylene, ethane, acetaldehyde, and ethanol production by plants under stress. J. Plant Physiol. 69, 840-847. doi: 10.1104/pp.69.4.840

Kirkendall, L. (1983). The evolution of mating systems in bark and ambrosia beetles (Coleoptera: scolytidae and Platypodidae). Zool. J. Linn. Soc. 77, 293-352. doi: 10.1111/j.1096-3642.1983.tb00858.x

Kostovcik, M., Bateman, C., Kolarik, M., Stelinski, L., Jordal, B., and Hulcr, J. (2015). The ambrosia symbiosis is specific in some species and promiscuous in others: evidence from community pyrosequencing. ISME J. 9, 126-138. doi: 10.1038/ismej.2014.115

Kovach, J., and Gorsuch, C. (1985). Survey of ambrosia beetle species' infesting South Carolina peach orchards and a taxonomic key for the most common species. J. Agric. Entomol. 2, 238-247.

Kuhnholz, S., Borden, J., and Uzunovic, A. (2001). Secondary ambrosia beetles in apparently healthy trees: adaptations, potential causes and suggested research. Integr. Pest Manage. Rev. 6, 209-219. doi: 10.1023/A:1025702930580

Lee, S., and Rose, J. (2010). Mediation of the transition from biotrophy to necrotrophy in hemibiotrophic plant pathogens by secreted efector proteins. Plant Signal. Behav. 5, 769-772. doi: 10.4161/psb.5.6.11778

Lehenberger, M., Benkert, M., and Biedermann, P. (2021). Ethanol-enriched substrate facilitates ambrosia beetle fungi, but inhibits their pathogens and fungal symbionts of bark beetles. Front. Microbiol. 11:590111. doi: 10.3389/ fmicb.2020.590111

Li, Q., Guo, H., Zhao, Y., Zhang, G., He, G., and Liu, B. (2015). Damage caused by Euwallacea fornicatus (Coleoptera: scolytidae) and its control techniques in Kunming. Plant Prot. 41, 193-196.

Li, Y., Gu, X., Kasson, M., Bateman, C., Guo, J., Huang, Y., et al. (2016). Distribution, host records, and symbiotic fungi of Euwallacea fornicatus
(Coleoptera: curculionidae: scolytinae) in China. Fla. Entomol. 99, 801-804. doi: 10.1653/024.099.0441

Lynch, S., Eskalen, A., and Gilbert, G. (2020). Host evolutionary relationships explain tree mortality caused by a generalist pest-pathogen complex. Evol. Appl. 2020, 1-12. doi: 10.1111/eva.13182

Lynch, S., Twizeyimana, M., Wang, D., Mayorquin, J., Na, F., Kayim, M., et al. (2016). Identification, pathogenicity, and abundance of Paracremonium pembeum sp. nov. and Graphium euwallaceae sp. nov. - two new mycangial fungal associates of the polyphagous shot hole borer (Euwallacea sp.) in California. Mycologia 108, 313-329. doi: 10.3852/15-063

Lynn, K., Wingfield, M., Duran, A., Marincowitz, S., Oliveira, L., de Beer, Z., et al. (2020). Euwallacea perbrevis (Coleoptera: curculionidae: scolytinae), a confirmed pest on Acacia crassicarpa in Riau, Indonesia, and a new fungal symbiont; Fusarium rekanum sp. nov. Antonie Van Leeuwenhoek 113, 803-823. doi: 10.1007/s10482-020-01392-8

MacDonald, R., and Kimmerer, T. (1991). Ethanol in the stems of trees. Plant Physiol. 82, 582-588. doi: 10.1111/j.1399-3054.1991.tb02950.x

Maffei, M., Mithofer, A., and Boland, W. (2007). Before gene expression: early events in plant-insect interaction. Trends Plant Sci. 12, 310-316. doi: 10.1016/j. tplants.2007.06.001

Martini, X., Hughes, M., Killiny, N., George, J., Lapointe, S., Smith, J., et al. (2017). The Fungus Raffaelea lauricola modifies behavior of its symbiont and vector, the redbay ambrosia Beetle (Xyleborus glabratus), by altering host plant volatile production. J. Chem. Ecol. 43, 519-531. doi: 10.1007/s10886-017-0843-y

Mendel, Z., Protasov, A., Maoz, Y., Maymon, M., Miller, G., Elazar, M., et al. (2017). The role of Euwallacea $n r$. fornicatus (Coleoptera: scolytinae) in the wilt syndrome of avocado trees in Israel. Phytoparasitica 45, 341-359. doi: 10.1007/s12600-017-0598-6

Moeck, H. (1970). Ethanol as the primary attractant for the ambrosia beetle Trypodendron lineatum (Coleoptera: scolytidae). Can. Entomol. 102, 985-995. doi: 10.4039/Ent102985-8

Mote, U., and Tambe, A. (1991). Observations on extent of damage caused by shot-hole borer on pomegranate and castor. J. Maharashtra Agric. Univ. 16, 439-440.

Ngoan, N., Wilkinson, R., Short, D., Moses, C., and Mangold, J. (1976). Biology of an introduced ambrosia beetle, Xylosandrus compactus, in Florida. Ann. Entomol. Soc. Am. 69, 872-876. doi: 10.1093/aesa/69.5.872

O’Donnell, K., Sink, S., Libeskind-Hadas, R., Hulcr, J., Kasson, M., and Ploetz, R. (2015). Discordant phylogenies suggest repeated host shifts in the Fusarium euwallacea ambrosia beetle mutualism. Fungal Genet. Biol. 82, 277-290. doi: 10.1016/j.fgb.2014.10.014

Oliver, J., and Mannion, C. (2001). Ambrosia beetle (Coleoptera: scolytidae) species attacking chestnut and captured in ethanol-baited traps in middle Tennessee. Environ. Entomol. 30, 909-918. doi: 10.1603/0046-225x-30.5. 909

Owens, D., Cruz, L., Montgomery, W., Narvaez, T., Schnell, E., Tabanca, N., et al. (2018). Host range expansion and increasing damage potential of Euwallacea nr. fornicatus (Coleoptera: curculionidae) in Florida. Fla. Entomol. 101, 229236. doi: 10.1653/024.101.0212

Owens, D., Seo, M., Montgomery, W., Rivera, M., Stelinski, L., and Kendra, P. (2019). Dispersal behaviour of Euwallacea nr. fornicatus (Coleoptera: curculionidae: scolytinae) in avocado groves and estimation of lure sampling range. Agric. For. Entomol. 21, 199-208. doi: 10.1111/afe.12321

Paap, T., de Beer, Z., Migliorini, D., Nel, W., and Wingfield, M. (2018). The polyphagous shot hole borer (PSHB) and its fungal symbiont Fusarium euwallaceae: a new invasion in South Africa. Australas. Plant Pathol. 47, 231-237. doi: 10.1007/s13313-018-0545-0

Ploetz, R., Hulcr, J., Wingfield, M., and de Beer, Z. (2013). Destructive tree diseases associated with ambrosia and bark beetles: black swan events in tree pathology? Plant Dis. 97, 856-872. doi: 10.1094/pdis-01-13-0056-fe

Rabaglia, R., Cognato, A., Hoebeke, E., Johnson, C., Labonte, J., Carter, E., et al. (2019). Early detection and rap $\iota$ d response; a 10-year summary of the USDA Forest Service Program of surveillance for non-native bark and ambrosia beetles. Am. Entomol. 65, 29-42. doi: 10.1093/ae/tmz015

Rabaglia, R., Dole, S., and Cognato, A. (2006). Review of American Xyleborina (Coleoptera: curculionidae: scolytinae) occurring North of Mexico, with an illustrated key. Ann. Entomol. Soc. Am. 99, 1034-1056. doi: 10.1603/00138746(2006)99[1034:roaxcc]2.0.co;2 
Ranger, C., Biedermann, P., Phuntumart, V., Beligala, G., Ghosh, S., Palmquist, D., et al. (2018). Symbiont selection via alcohol benefits fungus farming by ambrosia beetles. PNAS 115, 4447-4452. doi: 10.1073/pnas.1716852115

Ranger, C., Reding, M., Persad, A., and Herms, D. (2010). Ability of stress-related volatiles to attract and induce attacks by Xylosandrus germanus and other ambrosia beetles. Agric. Forest Entomol. 12, 177-185. doi: 10.1111/j.1461-9563. 2009.00469.x

Ranger, C., Schultz, P., Frank, S., Chong, J., and Reding, M. (2015). Non-native ambrosia beetles as opportunistic exploiters of living but weakened trees. PLoS One 10:e0131496. doi: 10.1371/journal.pone.0131496

Reding, M., and Ranger, C. (2020). Attraction of invasive ambrosia beetles (Coleoptera: curculionidae: scolytinae) to ethanol-treated tree bolts. J. Econ. Entomol. 113, 321-329. doi: 10.1093/jee/toz282

Rudinsky, J. (1962). Ecology of Scolytidae. Annu. Rev. Entomol. 7, 327-348. doi: 10.1146/annurev.en.07.010162.001551

Savatin, D., Gramegna, G., Modesti, V., and Cervone, F. (2014). Wounding in the plant tissue: the defense of a dangerous passage. Front. Plant Sci. 5:470. doi: $10.3389 /$ fpls.2014.00470

Schedl, K. (1963). Scolytidae und Platypodidae Afrikas, Band II. Rev. Entomol. MZN. 5, 1-594.

Schedl, K. E. (1942). Zur Scolytoiden-fauna der malayischen Halbinsel. V. Kolforstl. Mitt. 5, 169-218.

Schedl, K. E. (1951). Fauna indomalayaensis, I. Tijdschr. Entomol. 93, 41-98.

Six, D. (2012). Ecological and evolutionary determinants of bark beetle - fungus symbioses. Insects 3, 339-366. doi: 10.3390/insects3010339

Skelton, J., Johnson, A. J., Jusino, M. A., Bateman, C. C., Li, Y., and Hulcr, J. (2019). A selective fungal transport organ (mycangium) maintains coarse phylogenetic congruence between fungus-farming ambrosia beetles and their symbionts. Proc. R. Soc. B. 286:20182127. doi: 10.1098/rspb.2018.2127

Smith, R. (1972). Xylem Resin in the Resistance of the Pinaceae to Bark Beetles. General Technical Report PSW-1. Berkeley, CA: USDA Forest Service, Pacific Southwest Forest and Range Experiment Station, 7.

Smith, S., Gomez, D., Beaver, R., Hulcr, J., and Cognato, A. (2019). Reassessment of the species in the Euwallacea fornicatus (Coleoptera: curculionidae: scolytinae) complex after the rediscovery of the "lost" type specimen. Insects 10, 261-271. doi: 10.3390/insects 10090261

Soltis, D., Smith, S., Cellinese, N., Wurdack, K., Tank, D., and Brockington, S. (2011). Angiosperm phylogeny: 17 genes, 640 taxa. Am. J. Bot. 98, 704-730.

Speyer, E. (1917). Shot-hole borer investigations. Tropical Agriculturist 48, $152-$ 155.

Storer, C., Breinholt, J., and Hulcr, J. (2015). Wallacellus is Euwallacea: molecular phylogenetics settles generic relationships (Coleoptera: curculionidae: scolytinae: xyleborini). Zootaxa 3974, 391-400. doi: 10.11646/zootaxa.3974.3.6
Stouthamer, R. (2014). Foreign Exploration for the Polyphagous Shot Hole Borer and Associated Fungi in Viet Nam. Viet Nam exploration Feb $9^{\text {th }}$ - March $2^{\text {nd }}$, 2014. Available online at: https://www.californiaavocadogrowers.com/sites/ default/files/PSHB-Vietnam-Travel-Addendum-Report.pdf (accessed, March 2020).

Stouthamer, R., Rugman-Jones, P., Thu, P., Eskalen, A., Thibault, T., Hulcr, J., et al. (2017). Tracing the origin of a cryptic invader: phylogeography of the Euwallacea fornicatus (Coleoptera: curculionidae: scolytinae) species complex. Agric. For. Entomol. 19, 366-375. doi: 10.1111/afe.12215

Walgama, R. (2012). Ecology and integrated pest management of Xyleborus fornicatus (Coleoptera: scolytidae) in Sri Lanka. J. Integr. Pest Manage. 3, A1-A8. doi: 10.1603/IPM11031

Weber, B., and McPherson, J. (1983). World list of host plants of Xylosandrus germanus (Blandford) (Coleoptera: scolytidae). Coleopt. Bull. 37, 114-134.

Weber, B., and McPherson, J. (1984). Notes: attack on black walnut trees by the ambrosia beetle Xylosandrus germanus (Coleoptera: scolytidae). Forest Sci. 30, $864-870$.

Wood, S., and Bright, D. (1992). A catalog of scolytidae and platypodidae (Coleoptera), part 2: taxonomic index. Great Basin Nat. 13, 1-1533.

Wood, S. L. (1982). The Bark and Ambrosia Beetles of North and Central America (Coleoptera: Scolytidae), A Taxonomic Monograph. Great Basin Naturalist Memoirs No. 6. Provo, UT: Brigham Young University.

Wuest, C., Harrington, T., Fraedrich, S., Yun, H., and Sheng-Shan, S. (2017). Genetic variation in native populations of the laurel wilt pathogen, Raffaelea lauricola in Taiwan and Japan and the introduced population in the United States. Plant Dis. 101, 619-628. doi: 10.1094/pdis-10-161517-re

Yamada, T. (2001). Defense mechanisms in the sapwood of living trees against microbial infection. Jour. For. Rer. 6, 127-137. doi: 10.1007/BF02767083 doi: $10.1007 / \mathrm{bf} 02767083$

Conflict of Interest: The authors declare that the research was conducted in the absence of any commercial or financial relationships that could be construed as a potential conflict of interest.

Copyright (c) 2021 Mendel, Lynch, Eskalen, Protasov, Maymon and Freeman. This is an open-access article distributed under the terms of the Creative Commons Attribution License (CC BY). The use, distribution or reproduction in other forums is permitted, provided the original author(s) and the copyright owner(s) are credited and that the original publication in this journal is cited, in accordance with accepted academic practice. No use, distribution or reproduction is permitted which does not comply with these terms. 